\title{
Zbigniew Paszek
}

\section{METODOLOGIJA OCENE KVALITETA EDUKACIJE}

\begin{abstract}
Sažetak: Pred obrazovanje su postavljena dva osnovna zadatka: kontinuirano obezbeđenje i garancija kvaliteta visokog obrazovanja. Razvoj društva, globalizacija, razvoj tržišnih uslova u sistemu visokog obrazovanja i uspostavljeno tržište znanja traže usklađenost sistema visokog obrazovanja i oblikovanja jedinstvenog obrazovnog prostora. Iznalaze se novi putevi razvoja $i$ unapređenja visokoškolskog obrazovanja. Kvalitet obrazovanja u visokim školama poistovećuje se obično sa visokim standardima koji obavezuju akademskog nastavnika u toku realizacije didaktičkog procesa. U ovom radu izložena je procedura ocene kvaliteta obrazovanja koja utiče na povećanje kvaliteta didaktičkog procesa. Analizom rezultata dobijenih ispitivanjem studentskog mišljenja o kvalitetu rada akademskih nastavnika, cilj nam je da pokrenemo mogućnosti i perspektive u pravcu povećavanja kvaliteta visokog obrazovanja.
\end{abstract}

Ključne reči: kvalitet visokog obrazovanja, naučni kadar, studenti.

\section{METHODOLOGY OF ASSESSING QUALITY EDUCATION}

\begin{abstract}
The two main tasks are set in front of the education: continuous assurance and quality assurance in higher education. The development of society, globalization, the development of the market conditions in higher education system and the established knowledge market require to be in compliance with the higher education system and the formation of the unique space for education. The new ways of development and improvement of the higher education are found. The quality of education in higher schools is usually equated to the high standards which bind an academic teacher during the realization of the didactic process. In this paper, the quality assessment procedure for higher education, which influences an increase in quality of didactic process, is presented. With results analysis obtained during the examination of the students' opinion on the professional competence of the academic teachers, the aim is to start exploring possibilities and perspectives towards an increase in quality of higher education.
\end{abstract}

Keywords: quality of higher education, teaching staff, students.

\section{UVOD}

Sir Karl Popper, jedan od najistaknutijih filozofa nauke, u svom osnovnom delu „Logik der Forsuchung“ izdatom 1935. godine, a prevedenom na engleski jezik tek 1959. godine i izdatom pod naslovom „Logik of Scientific Discovery“, dovodio je u sumnju potrebu i celishodnost pojedinačnog definisanja svih pojmova potrebnih za analizu određenog problema. Naime, svaki put kada želimo definisati neki novi termin, $u$ njegovu definiciju moramo uvesti nove pojmove $\mathrm{i}$ onda te nove pojmove definisati.

Ipak, to ne znači da generalno treba odustati od definisanja pojmova i termina koji se upotrebljavaju, posebno kada su predmet razmatranja pojmovi sa više značenja kao što je kvalitet obrazovanja.

U opštoj teoriji upravljanja kvalitetom koriste se dve koncepcije definisanja kvaliteta. Naime, kvalitet može biti definisan kao skup osobina proizvoda koji je ocenjivan (tvorevine ili usluge), ili kao relacija između ovog skupa i potreba i preferencija primaoca proizvoda. Takav način definisanja kvaliteta izgleda da najviše odgovara u prezentovanom slučaju.

Kvalitet obrazovanja u visokim školama poistovećuje se obično sa visokim standardima koji obavezuju akademskog nastavnika u toku realizacije didaktičkog procesa. U situaciji kada je ,majstor“ koji je predavao sam stvarao uzorke i sam odlučivao o načinima i tehnikama predavanja znanja, problem ocene akademskih nastavnika u principu nije postajao, u smislu operativnog upravljanja procesom obrazovanja. Strukturalne

\footnotetext{
*Dr Zbigniew Paszek, profesor Krakovske akademije „Andrej Frič Modževski“, Krakov, Poljska, e-mail: zpaszek@afm.edu.pl.
} 
promene u organizaciji visokih škola, a pre svega masovno obrazovanje, dovele su do nestanka pozicije „majstora“ i do drugačijeg oblikovanja i shvatanja relacije: akademski nastavnik - student (Glasser, 1992; Glasser, 1992; citirano prema: Biel, Paszek, 2003: 89).

Merenje kvaliteta obrazovanja susreće se sa istim preprekama koje se u ekonomiji pojavljuju kod merenja korisnosti dobara. U praksi, merenje kvaliteta obrazovanja je moguće samo na rednom razmeru, odnosno naređenoj skali. Moguće je dakle uređenje posmatranih objekata ili varijanti, međutim nije moguće ocenjivanje distance između njih.

Mehanizmi i procedure koji se primenjuju u visokim školama ne garantuju uvek ispunjenje očekivanja u pogledu kvaliteta obrazovanja. Da bi se postigla očekivanja treba uvesti unutrašnji sistem koji obuhvata samoocenu visoke škole, njene didaktičke jedinice, ocenu u kategoriji normiranih pokazatelja kvaliteta, akademskih nastavnika i studenta, kao i spoljnji sistem (akreditaciju) koji obuhvata normiranu ocenu pokazatelja kvaliteta (Chmielecka, 2001; Debska, 2001; Galkowska, 1999; Kuberski, 2001; Niestrój, 1999; Strahl, 2001; citirano prema: Biel, Paszek, 2003: 89).

Primećujemo da se oseća nedostatak kompleksnog sistema regularno vršene kontrole i ocene didaktičkog procesa. Monitoring koji se odnosi uglavnom na efikasnost obučavanja, koji je meren ocenama, nije pravo rešenje. Na osnovu materijala prikupljenog u Ekonomskoj akademiji u Krakovu i u Školi poduzetništva i menadžmenta u Ekonomskoj akademiji u Krakovu, organizaciono izdvojene jedinice tog univerziteta, kao i u Krakovskoj akademiji „Andrej Frič Modževski“, izvršena je obrada rezultata dobijenih ispitivanjem studentskog mišljenja o kvalitetu rada akademskih nastavnika. Cilj ovog rada je prezentovanje ove metodologije i rezultata dobijenih u izvršenim ispitivanjima (Biel, Paszek, 2003: 90).

Meritorna hipoteza: Procedura ocene kvaliteta obrazovanja, koja predložena u ovom radu, na značajan način utiče na povećanje kvaliteta didaktičkog procesa (Biel, Paszek, 2003: 90).

\section{POSTDIPLOMSKE STUDIJE - IZVANREDNA FORMA OBRAZOVANJA}

U periodu društveno-ekonomskih i političkih promena, neophodna stvar postaje izrada novog sistema obrazovanja, posebno u finansijskom aspektu, i njegovo prilagođavanje neprestano promenljivim uslovima u radu visokih škola. Primer takvih sistema su postdiplomske studije, koje među raznim formama obrazovanja nesumnjivo imaju najveću popularnost.

Postdiplomske studije organizovane su za apsolvente visokih škola, koji nastoje da prodube i sistematizuju svoje znanje stečeno za vreme studija, prošire ga za najnovija dostignuća nauke i da se, zahvaljujući diplomskom radu, upoznaju sa procedurama koje se mogu primenjivati u privredi. Na kraju, od velike važnosti je mogućnost pogleda na mnoge praktične i teorijske probleme sa potpuno drugačije tačke gledišta u odnosu na one koje su im predstavljene za vreme studija. Takođe je važno obratiti pažnju na društveni aspekt, zahvaljujući kome postdiplomci imaju mogućnost da se bliže upoznaju, razmene mišljenja, a nekada i da preduzimaju zajednički rad primenljivog karaktera, korisnog za preduzeća koja su ih poslala na te studije.

\section{KRITERIJUMI IZBORA NAUČNOG KADRA}

Kao što je poznato, visok kvalitet obrazovanja omogućava ne samo pravi izbor naučnog kadra, već i odgovarajuće izrađen program nastave, metoda učenja kao i savremenu opremu koja se nalazi u učionicama i kompjuterskim salama sa najnovijim vrstama programa.

U Krakovskoj akademiji „Andrej Frič Modževski“, koja je u sastavu Krakovskog ekonomskog univerziteta, nastavu vrše naučni radnici kao i specijalisti-praktičari. U slučaju naučnih radnika osnovni kriterijum pri zapošljavanju je njihov naučno-nastavni doprinos kao i iskustvo u oblasti predavanog predmeta. Kada se radi o specijalistima-praktičarima, profesionalna dostignuća imaju presudnu ulogu. U oba slučaja u obzir se uzima profil ličnosti, nastavne predispozicije i profesionalna etika. Stalo nam je da naučni kadar prenosi znanje koje obuhvata najnovije svetske tendencije u oblasti predavane discipline, ne zaboravljajući pri tome da nema ništa bolje od prakse koja je zasnovana na teoriji. 
Brinući za visok nivo nastave, velika pažnja posvećuje se mišljenju redovnih, vanrednih i postdiplomskih studenata. Treba podvući da to mišljenje, koje se iskazuje putem anonimnih anketa, ne služi samo za ocenu kvaliteta obrazovanja, već i kao važan kriterijum pri zapošljavanju predavača.

\section{KVALITET OBRAZOVANJA}

Na početku vredi pomenuti pojam kvaliteta, koji se, kao što je poznato, definiše na razne načine. Kvalitet se može posmatrati kao filozofska kategorija, ili kao tehnička, ekonomska ili marketinška kategorija. Nas interesuje kvalitet proizvoda koji podrazumeva problem zadovoljavanja potreba. Intuitivno razumevanje kvaliteta proizvoda (ili usluga) ne stvara probleme. Međutim, oni se pojavljuju prilikom pokušaja da se on precizno definiše. Na osnovu norme PN-EN ISO 9000, kvalitet je stepen u kome zbir osnovnih svojstava ispunjava zahteve odnosno „potrebu ili očekivanje, koje je određeno, opšte prihvaćeno ili obavezno“.

$\mathrm{Na}$ visokim školama se u poslednje vreme dosta piše i diskutuje o kvalitetu obrazovanja. Ispostavlja se da naučni radnici nemaju uvek isti pristup ovom pojmu.

U akademskoj sredini obično se oslanjalo na tradiciju, u kojoj je kvalitet akademskog obrazovanja bio identifikovan na osnovu izuzetno visokih standarda.

U literaturi se kvalitet obrazovanja različito definiše. Uglavnom se usvaja da proces obrazovanja obuhvata sledeće elemente: samoobrazovanje i uticaj okruženja na obrazovanje. Uticaj okruženja na obrazovanje obuhvata: bliže okruženje, uglavnom porodicu i prijatelje, naučni kadar, dalje okruženje, odnosno sredinu u kojoj živimo, studiramo, radimo, uticaj načina percepcije, reakcije sredine i refleksije vezane za njega, razmišljanja, očekivanja i drugi faktore. Kvalitet obrazovanja je dakle funkcija pomenutih elemenata (Kształcenie, 2008).

Čini se ipak da je najtačnija i sa praktične strane najkorisnija definicija autora Jerza Dietla da kvalitet obrazovanja predstavlja prenošenje studentima metodoloških i intelektualnih osnova za posao u biznisu, $u$ uslovima brzih promena u okruženju, intenzivnosti konkurencije i globalizacije tržišta. Sticanje veština učenja omogućava u profesionalnoj delatnosti produbljivanje opšteg i specijalističkog znanja, koje omogućava upravljanje izabranim funkcijama preduzeća. Prenošenje ne samo sistemski stečenog znanja, nego i razvoj određenih veština, konkretno: vođstva, saradnje u okviru timova, komunikacije sa okruženjem, pregovaranja i preduzimanja i osiguranja ekonomskog rizika (Dietl, 1997: 27-28).

\section{Faktori koji utiču na porast nivoa kvaliteta obrazovanja}

- Pravilno finansiranje naučnoistraživačke i nastavne delatnosti.

- Uvođenje koncepta menadžmenta ukupnog kvaliteta (TQM).

- Izrada programa učenja saglasno sa državama koje karakteriše visok nivo privrednog razvoja.

- Uvođenje pravila mogućnosti izbora predavača od strane studenata.

- Pozitivna selekcija za vreme prijema kandidata na posao u visokim školama.

- Sistematsko obrazovanje mladih naučnih radnika, pogotovu preko inostranih stipendija na poznate visoke škole u svetu.

- Opravdano ograničenje prijema na studije.

- Organizovanje delatnosti studentskih naučnih grupa.

- Uvođenje pravila zajedničkih istraživanja (naučnih radnika sa radnicima preduzeća) u oblasti biznisa.

- Evaluacija kvaliteta obrazovanja.

- Vršenje ispitivanja nad rezultatima obrazovanja.

- Akreditacija, validacija, koncesija i licenciranje.

- Istraživanja u oblasti karijere apsolvenata. 
Rezimirajući, može se reći da kvalitet obrazovanja predstavlja prilagođavanje radnji realizaciji postavljenih ciljeva. Važan element za osiguranje visokog nivoa kvaliteta obrazovanja jeste povezivanje teoretskog i praktičnog znanja, koje se prenosi studentima biznisa. Preko univerzalnosti treba dalje težiti korisnosti obrazovanja.

Ocena kvaliteta obrazovanja u visokim školama vrši se preko realizacije programa učenja, obezbeđenja visokokvalifikovanog naučnog kadra, kao i unutrašnjeg sistema koji obezbeđuje visok nivo predavanja.

Kao što je već pomenuto, nivo predavanja ocenjuju studenti popunjavanjem odgovarajuće pripremljenih anketa.

Proces sistematičnog skupljanja podataka i analiza, iskorišćavanjem odgovarajućih statističkih programa, omogućava konstantan monitoring veza koje nastaju između studenata i naučnog kadra. Unutrašnji sistem kontrole efektivnosti nastavnog procesa omogućava oblikovanje efikasnih nastavnih metoda, zahvaljujući kojima studenti najbolje savladavaju oblast znanja koje zahteva predavač sa istovremenim utiskom korisnosti tog znanja u biznisu.

\section{Karakteristika istraživačkog materijala}

Anketna istraživanja posvećena mišljenju studenta o kvalitetu rada akademskih nastavnika obuhvatale su sve grupe didaktičkih radnika visoke škole, to jest: profesore sa zvanjem, profesore Ekonomske akademije, docente, starije predavače, predavače, asistente, lektore i instruktore. Najveću grupu ocenjivanih u prvom od razmatranih perioda su činili asistenti (170) i doktori (140), zatim stariji predavači (64), profesori sa zvanjem (42), profesori Ekonomske akademije (50), predavači (6) i docenti (2). U opisivanom periodu nije prikupljeno mišljenje o lektorima i osobama zaposlenim na mestu instruktora i nastavnika fizičkog vaspitanja (Biel, Paszek,2003: 90).

\section{Istraživačka procedura}

Sprovođenje anketa, u skladu s prihvaćenom procedurom, vršeno je od strane deset anketara - radnika Ekonomske akademije, u poslednje dve nedelje pre zimskog i letnjeg ispitnog roka (Biel, Paszek, 2003: 105).

Anketno ispitivanje se ticalo četiri kriterijuma ocenjivanja rada akademskog nastavnika: metodički (način organizacije vežbi), predmetni (način prezentovanja predmeta, da li aktivira studente), formalni (koji se odnosi na disciplinu rada sa studentima) i relativni (lični odnos prema studentima). Formulisanje mišljenja se svodilo na opisivanje, korišćenjem skale od 1 do 5 (Biel, Paszek, 2003: 92-93).

\section{Obrada rezultata}

Pomoću modula kompjuterskog programa (SABA) formirano je nekoliko opštih profila didaktičkog stava, koji približno oslikavaju kako se kod studenta na izabranih pet smerova studija stvara mišljenje o kvalitetu didaktičkog procesa. Drugim rečima, kako oni posmatraju svoje akademske nastavnike (Biel, Paszek, 2003: 102).

\section{KRAJNJI ZAKLJUČCI}

Analiza ispitivanja koja je prezentovana u ovom radu, a koja je izvršena na osnovu monitoringa, omogućava nam da formulišemo sledeće zaključke (Biel, Paszek, 2003: 102-103):

1. Trogodišnji proces vršenja ispitivanja iste grupe akademskih nastavnika nam omogućava da formulišemo verodostojne ocene.

2. Predložena procedura ocene kvaliteta obrazovanja pruža bitne informacije o organizaciji didaktičkog procesa, o nepravilnostima u planiranju i držanju vežbi. Ona disciplinuje akademske nastavnike, a studentima pruža mogućnost uticanja na nivo kvaliteta održanih vežbi. Zahvaljujući ovim ispitivanjima studenti aktivno učestvuju u nastavnom procesu, osećaju da im je porasla vrednost i u višem stepenu se identifikuju sa svojom visokom školom. 
3. Kako je pokazalo ispitivanje o oceni kvaliteta rada akademskog nastavnika, prosečna ocena studenta, koji popunjavaju anketu nema uticaja, što svedoči o njihovom poštenom shvatanju anketnih ispitivanja.

4. Zaključci formulisani na osnovu anonimnih rezultata anketa se odnose na modifikaciju strukture i sadržaja programa (na primer: spajanje dva srodna petnaestosatna predmeta u jedan), primenjivanih didaktičkih metoda, kao i promena u timu akademskih nastavnika. Šefovi katedri, zahvaljujući mišljenju o kvalitetu rada zaposlenih akademskih nastavnika, imaju mogućnost izbora i poveravanja vežbi najboljim akademskim nastavnicima, kao i vršenja selekcije zaposlenih asistenata.

5. U slučaju podvrgavanja akreditacionoj proceduri budućih smerova na fakultetu, predložena metodologija može da ima bitnog uticaja, kao jedan od izvora verodostojnih informacija o nivou obrazovanja od strane pojedinih akademskih nastavnika.

6. Između četiri smera studija, najgore ocene su dobili akademski nastavnici koji drže didaktičke vežbe na smeru informatika i ekonometrija.

7. U mnogim komentarima u studentskim anketama ponavlja se njihovo očekivanje da se izvuku pouke (konsekvence) upućene onim osobama koje loše drže vežbe.

8. Javno priznanje za najbolje akademske nastavnike utiče na mobilizaciju i motiviše sve akademske nastavnike.

9. Nasuprot pretpostavkama, nije uvek matematički predmet dobijao niske ocene studenta. Očigledno je da uvek u takim slučajevima odlučnu ulogu igra profesionalizam akademskog nastavnika, što studenti znaju pravilno da ocene.

10. Kako proizilazi iz komentara upisanih u anketama, svest studenta je toliko porasla da ih ne zadovoljavaju akademski nastavnici, koji su doduše simpatični, ali koji ne drže vežbe na profesionalan način, a zadovoljavaju ih pre svega kompetentni, čak i oni koji puno zahtevaju, tj. stručnjaci.

11. Prezentovana ispitivačka procedura će doneti konkretan rezultat samo onda kada akademski nastavnici budu ocenjivani sistematično i ciklično.

12. Vredi podvući da je anketa samo jedan od elemenata sistema obezbeđivanja kvaliteta obrazovanja, koji se koristi u verifikaciji primenjivanih mehanizama didaktičkog procesa.

\section{LITERATURA}

[1] Biel, K., Paszek, Z., (2003) Assessing the Quality of Academic Teaching, „Zeszyty Naukowe“, No. 1, pp. 89-119.

[2] Chmielecka, E., (2001) Akredytacja wyźszych studiów ekonomicznych w Polsce [w:] Dydaktyka XXI wieku, Materiały sympozjum naukowego z okazji 10-lecia Szkoły Przedsiębiorczości i Zarządzania Akademii Ekonomicznej w Krakowie, pod red. Steczkowskiego, J., Kraków, AE w Krakowie.

[3] Chmielecka, E., (2001) Procesy zwiqzane z tworzeniem standardów akredytacyjnych [w:] Akredytacja programów dydaktycznych i uczelni z dróg podniesienia jakości nauczania, Materiały konferencyjne, pod red. Dietla, J. , Sapijaszki, Z., Łodź, Fundacja Edukacyjna Przedsiębiorczości.

[4] Dietl, J., (1997) Kvalitet obrazovanja na osnovnim strukovnim studijama - Osnovne studije za potrebe biznisa, dosadašnja iskustva i dalje perspektive, Łódź, FEP.

[5] Gałkowska, A., Kluska, R., (1999) Procedura oceniania pracowników w aspekcie jakości ksztalcenia [w:] Systemy wartościowania wiedzy, Materiały z Konferencji Rektorów i Załoźycieli Uczelni Niepaństwowych, Rzeszów, Wyźsza Szkoła Informatyki i Zarządzania w Rzeszowie.

[6] Glasser, W., (1992) The Quality School Teacher: A Companion Volume to the Quality School, New York, Harper Perennial.

[7] Glasser, W., (1992) The Quality School: Managing Students Without Coersion, New York, Harper Perennial. 
[8] Kształcenie, preuzeto septembra 2012. godine sa sajta: http://mfiles.pl/plindex.php/Kszta\%C5\%82cenie.

[9] Kuberski, L., (2001) Ankiety studenckie jako narzędzie doskonalenia jakości ksztalcenia na Uniwersytecie Opolskim [w:] Akredytacja programów dydaktycznych i uczelni jedna z dróg podniesienia jakości nauczania, Materiały konferencyjne, pod red. Dietla, J., Sapijaszki, Z., Łódź, Fundacja Edukacyjna Przedsiębiorczości.

[10] Niestrój, R., (1999) Systemy kredytowe i punktowe - cele zaloźenia, wdraźanie [w:] Systemy wartościowania wiedzy. Materiały z Konferencji Rektorów i Załoźycieli Uczelni Niepaństwowych. Rzeszów: Wyźsza Szkoła Informatyki i Zarządzania w Rzeszowie.

[11] Strahl, D., (2001) Proces akredytacji w państwowych uczelniach ekonomicznych $w$ Polsce - zaloźenia i perspektywy [w:] Akredytacja programów dydaktycznych i uczelni jedna z dróg podniesienia jakości nauczania, Materiały konferencyjne, pod red. Dietla, J., Sapijaszki, Z., Łódź, Fundacja Edukacyjna Przedsiębiorczości. 


\section{PRILOG A - UZORCI ANKETA ${ }^{1}$}

\section{EKONOMSKA AKADEMIJA U KRAKOVU \\ MIŠLJENJE STUDENATA O AKADEMSKOM NASTAVNIKU}

Cilj anketnih ispitivanja je povećanje nivoa didaktike na univerzitetu.

Upitnik pomaže u prikupljanju podataka o mišljenju studenata o načinu održavanja didaktičkih vežbi.

Rezultati ispitivanja će biti predati pojedinim didaktičkim radnicima nakon ispitnog roka.

Anketa je anonimna. Molimo Vas za ozbiljnost prilikom popunjavanja upitnika.

Tokom popunjavanja upitnika treba tačno potamniti (tamnoplavom ili crnom bojom) polje izabranog odgovora, na primer ovako:

Ne smete uvoditi nikakve druge oznake, kao što su:

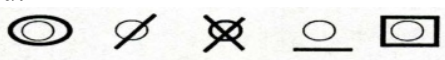

PAŽNJA! FORMULAR SE NE SME GUŽVATI I SAVIJATI.

Predavač - (NE UPISIVATI PREZIME)

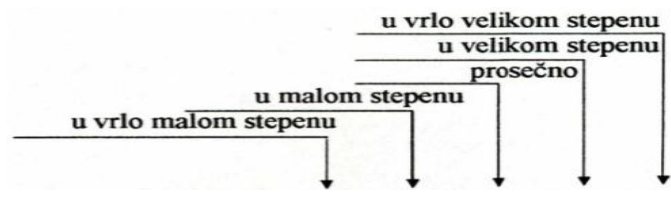

1. Dobro organizuje predavanja.

2. Drži predavanja regularno i tačno.

3. Prema studentima se ponaša taktički i prijateljski.

4. Određuje jednoznačno zahteve prema studentima

5. Inspiriše studente da razmišljaju samostalno.

6. Predaje gradivo jasno i precizno.

7. Realizuje jasno određeni cilj predavanja.

8. Drži predavanja na interesantan način.

9. Dostupan je studentima u određeno vreme

10. Povezuje teoretska razmatranja sa društveno-privrednom praksom.

11. U toku predavanja služi se modernim didaktičkim pomagalima.

12. Informiše studente o programu predmeta.

13. Studiranje predmeta zahteva čitanje specijalističke................ literature

14. Nivo tvoje zainteresovanosti predmetom.

15. Prosečna ocena u zadnjem ispitnom roku.

16. Broj vežbi na kojima ste bili odsutni.

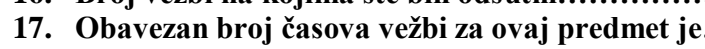

\section{PRIMEDBE:}

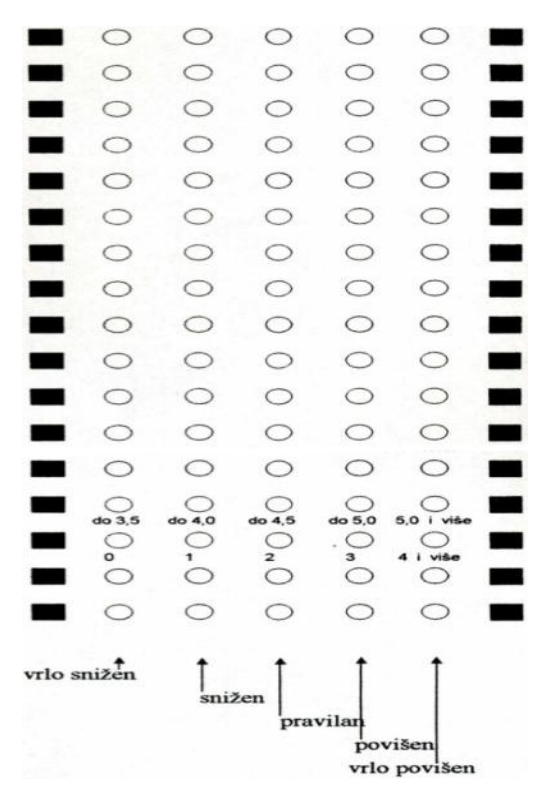

Zahvaljujemo na popunjavanju ankete.

\footnotetext{
${ }^{1}$ Biel, Paszek (2003: 112-115).
} 
PAŽNJA! FORMULAR SE NE SME GUŽVATI I SAVIJATI.

Osoba koja drži vežbe - (NE UPISIVATI PREZIME)

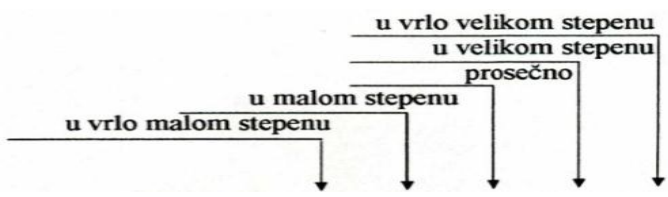

1. Dobro organizuje vežbe.

2. Drži vežbe regularno i tačno.

3. Prema studentima se ponaša taktičku i prijateljski

4. Određuje jednoznačno zahteve prema studentima

5. Inspiriše studente da razmišljaju samostalno.

6. Predaje gradivo jasno i precizno.

7. Realizuje jasno određen cilj vežbi.

8. Drži vežbe na interesantan način.

9. Dostupan je studentima u određeno vreme

10. Povezuje teoretska razmatranja sa društveno-privrednom praksom

11. U toku vežbi služi se modernim didaktičkim pomagalima.

12. Informiše studente o programu predmeta.

13. Objektivno ocenjuje studente na vežbama

14. Studiranje predmeta zahteva čitanje specijalističke literature

15. Nivo tvoje zainteresovanosti predmetom.

16. Prosečna ocena u zadnjem ispitnom roku..

17. Broj vežbi na kojima ste bili odsutni.

18. Obavezan broj časova vežbi za ovaj predmet je.

PRIMEDBE:

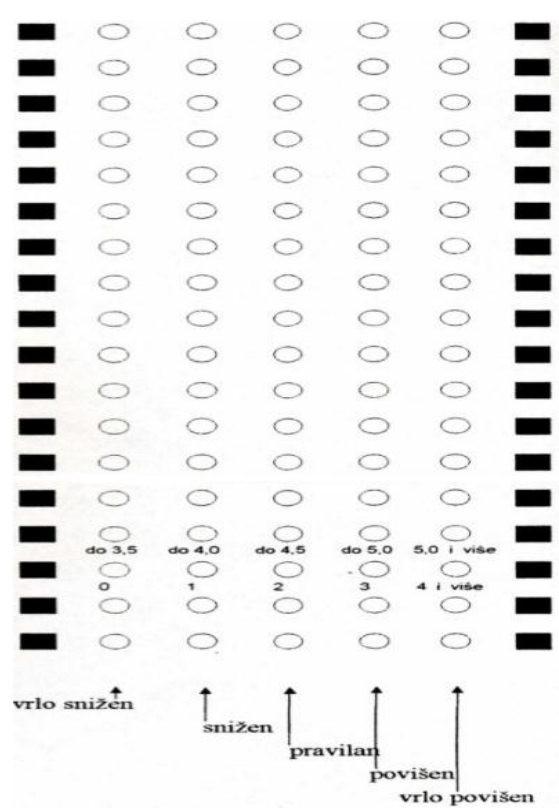

Zahvaljujemo na popunjavanju ankete.

PAŽNJA! FORMULAR SE NE SME GUŽVATI I SAVIJATI.

Osoba koja drži vežbe - (NE UPISIVATI PREZIME)

1. Dobro organizuje vežbe...

2. Drži vežbe regularno i tačno.

3. Prema studentima se ponaša taktički i prijateljski.......................

4. Određuje jednoznačno zahteve prema studentima.

5. Sporazumeva se sa studentima jasno i precizno.

6. Brine o prihvatanju bogatog leksičkog fonda.

7. Vežba umeće primenjivanja gramatičkih pravila

8. Drži vežbe na način koji aktivira studente.

9. Postavlja visoke zahteve studentima.

10. Podučava studente da se služe svakodnevnim jezikom.

11. Objektivno ocenjuje zalaganje rada studenata

12. Nivo tvoje zainteresovanosti predmetom.

13. Prosečna ocena u zadnjem ispitnom roku.

14. Broj vežbi na kojima ste bili odsutni.

15. Obavezan broj časova vežbi za ovaj predmet je.

PRIMEDBE:
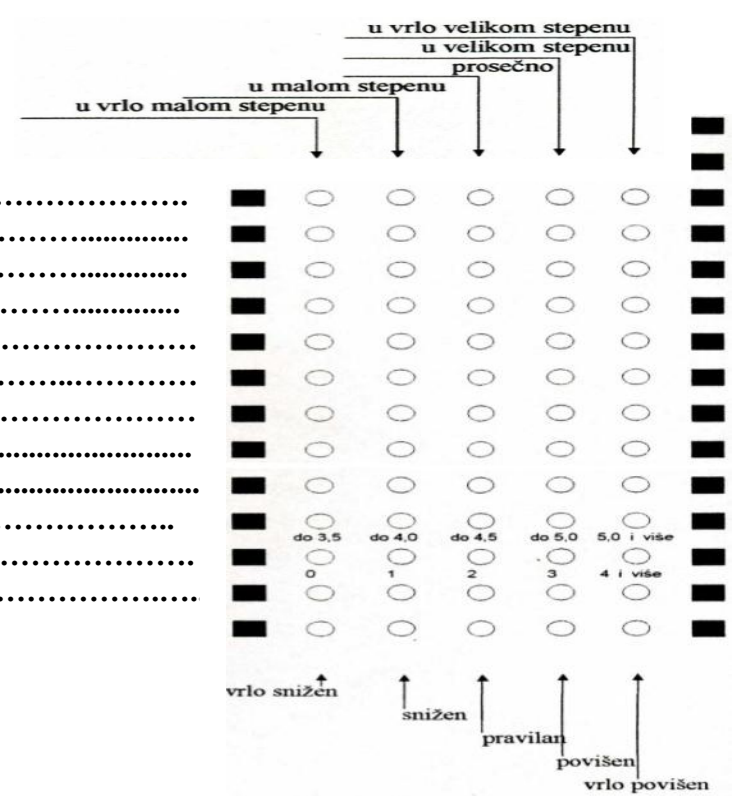

Zahvaljujemo na popunjavanju ankete. 
PRILOG B - PITANJA I ODGOVORI STUDENATA

\begin{tabular}{|c|c|c|c|}
\hline $\begin{array}{c}\text { Broj } \\
\text { pitanja }\end{array}$ & Pitanje & Odgovor & Anketirani studenti (\%) \\
\hline \multirow{4}{*}{1.} & \multirow{4}{*}{ Da li su svi časovi održani po planu? } & $\mathrm{da}$ & 100,00 \\
\hline & & uglavnom da & 0,00 \\
\hline & & uglavnom ne & 0,00 \\
\hline & & ne & 0,00 \\
\hline \multirow{2}{*}{2.} & \multirow{2}{*}{ Da li je nastavnik predložio vreme konsultacija? } & da & 100,00 \\
\hline & & ne & 0,00 \\
\hline \multirow{4}{*}{3.} & \multirow{4}{*}{ Da li su časovi počinjali i završavali se na vreme? } & da & 100,00 \\
\hline & & uglavnom da & 0,00 \\
\hline & & uglavnom ne & 0,00 \\
\hline & & ne & 0,00 \\
\hline \multirow{4}{*}{4.} & \multirow{4}{*}{ Da li su poruke prenošene na razumljiv način? } & da & 100,00 \\
\hline & & uglavnom da & 0,00 \\
\hline & & uglavnom ne & 0,00 \\
\hline & & ne & 0,00 \\
\hline \multirow{2}{*}{5.} & \multirow{2}{*}{$\begin{array}{l}\text { Da li je nastavnik predstavio jasna pravila } \\
\text { ocenjivanja na početku ciklusa predavanja? }\end{array}$} & da & 100,00 \\
\hline & & ne & 0,00 \\
\hline \multirow{4}{*}{6.} & \multirow{4}{*}{$\begin{array}{l}\text { Da li biste želeli da nekada ponovo učestvujete na } \\
\text { predavanjima tog nastavnika? }\end{array}$} & $\mathrm{da}$ & 100,00 \\
\hline & & uglavnom da & 0,00 \\
\hline & & uglavnom ne & 0,00 \\
\hline & & ne & 0,00 \\
\hline \multirow{2}{*}{7.} & \multirow{2}{*}{ Da li ste išli na konsultacije van nastave? } & $\mathrm{da}$ & 42,86 \\
\hline & & ne & 57,14 \\
\hline \multirow{4}{*}{8.} & \multirow{4}{*}{ Da li je nastava sprovođena na interesantan način? } & $\mathrm{da}$ & 100,00 \\
\hline & & uglavnom da & 0,00 \\
\hline & & uglavnom ne & 0,00 \\
\hline & & ne & 0,00 \\
\hline \multirow{4}{*}{9.} & \multirow{4}{*}{ Da li biste želeli da ovaj predmet duže traje? } & $\mathrm{da}$ & 85,71 \\
\hline & & uglavnom da & 14,29 \\
\hline & & uglavnom ne & 0,00 \\
\hline & & ne & 0,00 \\
\hline \multirow{4}{*}{10.} & \multirow{4}{*}{ Učestvovao/la sam u nastavi } & uvek & 100,00 \\
\hline & & uglavnom & 0,00 \\
\hline & & ponekad & 0,00 \\
\hline & & ne & 0,00 \\
\hline
\end{tabular}




\section{PRILOG C - IZABRANI PRIMERI SVOJERUČNO UPISANIH KOMENTARA U ANKETAMA STUDENTA (ZADRŽANA JE ORIGINALNA STILISTIKA) ${ }^{2}$}

\section{Pozitivne ocene}

1. Osoba koja drži vežbe poseduje široko znanje i zna da zainteresuje svojim znanjem studente. Podstiče na razmišljanje i u stanju je da angažuje studente da rade. Vredi istaći da drži vežbe na dva jezika.

2. Dobar didaktičar, prijateljski nastrojen prema studentima, podstiče na samostalno razmišljanje i proširivanje znanja u određenom opsegu.

3. Po mom mišljenju on je najbolji predavač u ovom semestru. Predavanja su vršena u prijatnoj atmosferi, a predavano je na jasan i čitljiv način.

4. Vežbe su zanimljive, omogućavaju prenos teoretskog znanja u praksu. Osoba koja drži vežbe je kompetentna, a vežbe su zanimljive. Umesto dva sata predavanja i dva sata vežbi voleo bih sat predavanja i tri sata vežbi.

5. U odnosu na tako beznadežan i besmislen predmet, osoba koja ga drži je izuzetna. Ocena predmeta: 2,0 , a ocena za osobu koja ga drži: 5,0.

6. Izvrsno održane vežbe. Vidi se da voli to što radi i radi sa pažnjom.

7. Jedno od najbolje održanih predavanja na ovom univerzitetu. Ovaj gospodin se zaista posvećuje onome što radi. Ja sam na IV godini i to je prvo predavanje koje smatram da je izuzetno.

8. Po mom mišljenju XX je izvanredna osoba. Zna da predaje jasno i precizno, često sa humorističkim akcentima. Veoma je prijateljski nastrojena prema studentima - uvek pomaže tamo gde treba. Sami superlativi!

9. Kompetentan, zna jasno objasniti gradivo. Principi dobijanja potpisa iz radova su jasni. Jedan od retkih koji znaju zašto rade na univerzitetu.

10. Jedna od najboljih osoba koje drže vežbe na interesantan način, puno praktičnih primera.

\section{Negativne ocene}

1. Predavač ne zna da se služi mikrofonom, ima problema s predavanjem, njegovi pomoćni materijali koji su prikazivani na foliji uopšte nisu čitljivi, njegove šale često nisu na mestu.

2. Magistar je nedostupan čovek, neprijatan i pakostan prema studentima. Često govori nešto drugo, a ne ono što kasnije zahteva od nas.

3. Na ispitu, bez obzira na to da li student napiše tačne odgovore, on dobija jako nisku ocenu, osim ukoliko ne napiše reč po reč kako je bilo na predavanju ili kako je u knjizi, pre svega u njegovoj knjizi.

4. To je već treći predmet tokom studija koji drži ista osoba i ta predavanja se zaista malo razlikuju. To je ponavljanje po treći put onoga što smo već čuli, samo pod drugim nazivom.

5. Predmet jeste odličan, ali osoba koja drži predavanja je beznadežna. Uopšte se ne koncentriše na predmet koji predaje. Govori o glupostima, a predmet je jako važan. U razmeru $0-10$, ocena 0.

6. Manje praznih priča o glupostima i bilo bi dobro. Poseduje vrlo veliko praktično znanje, ali ne zna da ga prenese. Malo više želje i angažovanja, gospodine doktore. Univerzitet nije cirkus. Treba dugo čekati da se čuje nešto meritorno.

7. Nikada nisam sreo predavača kome bih mogao da nađem toliko zamerki kao njoj. Gospođa doktor nije pripremljena za vežbe, već stalno diktira informacije iz istih listića. Drži vežbe za tri grupe istovremeno, na kojima se ništa ne može čuti, niti zabeležiti.

\footnotetext{
${ }^{2}$ Biel, Paszek (2003: 116-117).
} 
8. Profesor ima ekstremne poglede. Sve vreme na predavanjima kritikuje (veoma oštro) neke političare. Vređa njih i neke radnike našeg univerziteta. Na svakom predavanju previše se hvali bogatstvom i poznanstvima.

9. Predmet bi mogao biti interesantan, ali osoba koja drži vežbe je slaba, dosadna, bezizražajna, ne zna o čemu se radi, priča neke sasvim nepotrebne gluposti.

10. Želim skrenuti pažnju na nedopustiv program naših studija. Osećam se kao neznalica u oblasti ekonomije. Na desetinama predmeta predavanja su površna. Možda manje teorije, a više konkretnih stvari.

Primljeno: 05.09.2012.

Odobreno: 17.10.2012. 